\title{
SYMBOLICZNE WYOBRAŻENIA KOŚCIOŁA W PERYKOPACH BIBLIJNYCH PROKLAMOWANYCH W LITURGII OBRZĘDÓW POŚWIĘCENIA KOŚCIOŁA
}

DOI: http://dx.doi.org/10.12775/TiCz.2017.047

Pismo Święte ukazuje relacje Boga z ludźmi za pomocą wielu symboli, nazw i obrazów wziętych z życia narzeczeńskiego i małżeńskiego, rolniczego i pasterskiego, a nawet $\mathrm{z}$ budownictwa. Słowo Boże odsłania człowiekowi tajemnicę Boga i pomaga mu zrozumieć Jego działanie w historii zbawienia. Każde zbawcze działanie Boga poprzedza Jego słowo, poprzez które człowiek jest zdolny zrozumieć zbawcze wydarzenie.

W chrześcijańskiej liturgii proklamowane słowo Boże rodzi wiarę oraz przygotowuje do przyjęcia i zrozumienia sakramentu. Słowo to objaśnia istotę czynności sakramentalnej i rodząc wiarę, pozwala człowiekowi doświadczyć zbawczego działania Boga. Sobór Watykański II, wracając do starożytnej Tradycji Kościoła, przywrócił właściwe miejsce dla sło-

* Ks. dr hab. prof. UAM Dariusz Kwiatkowski, Kierownik Zakładu Liturgiki i Homiletyki na Wydziale Teologicznym Uniwersytetu im. Adama Mickiewicza w Poznaniu, Przewodniczący Wydziału Liturgii i Dyscypliny Sakramentów w Kurii Diecezji Kaliskiej (kwiatkowski@post.pl). 
wa Bożego w liturgii oraz obficie zastawił jego stół ${ }^{1}$. W zreformowanej liturgii praktycznie w każdej celebracji liturgicznej znajduje się miejsce dla proklamacji słowa Bożego. Dotyczy to zarówno sakramentów, jak i sakramentaliów. Przywrócenie czytań biblijnych do liturgii Kościoła wiąże się z nauczaniem konstytucji liturgicznej Sacrosanctum concilium o obecności Chrystusa w głoszonym słowie Bożym².

Liturgia słowa Bożego w Obrzędach poświęcenia Kościoła rozpoczyna się od bardzo wymownych czynności. Najpierw lektorzy czytający słowo Boże oraz psałterzysta podchodzą do biskupa z Lekcjonarzem mszalnym i podają mu go. Biskup, biorąc księgę w swoje ręce, wypowiada formułę: „Niech w tej świątyni rozbrzmiewa słowo Boże, aby wam odsłaniać tajemnicę Chrystusa i przyczyniać się do waszego zbawienia w Kościele”3. Formuła ta objaśnia i uzasadnia wiernym sens głoszenia słowa Bożego w liturgii Kościoła. Proklamowane słowo ma odsłaniać tajemnicę Chrystusa obecnego w Kościele i w sakramentalnych znakach oraz przyczyniać się do zbawienia. Celem artykułu jest przedstawienie symbolicznych wyobrażeń Kościoła w czytaniach biblijnych przewidzianych na liturgiczny obrzęd poświęcenia nowego Kościoła. Każda z tych nazw i metafor posiada swoją szczególną treść, którą trzeba właściwie zrozumieć, aby odkryć tajemnicę Chrystusowego Kościoła, którego znakiem jest każdy kościół wybudowany przez ludzi na ziemi . Drogą do realizacji postawionego celu będzie egzegeza wybranych perykop biblijnych przeznaczonych na dzień poświęcenia kościoła i umieszczonych w Lekcjonarzu mszalnym ${ }^{5}$.

1 Por. KL 51.

2 Tamże, 7.

3 Pontyfikał Rzymski odnowiony zgodnie z postanowieniem świętego Soboru Powszechnego Watykańskiego II wydany z upoważnienia papieża Pawła VI, poprawiony staraniem papieża Jana Pawła II. Obrzędy poświęcenia kościoła i ołtarza, Wydanie wzorcowe, Katowice 2001, s. 49, nr 53 (dalej: OPKiO).

${ }^{4}$ Por. E. Ozorowski, Kościót, Wrocław 1984, s. 49.

${ }_{5}^{5}$ Lekcjonarz mszalny, t. VI, Poznań-Warszawa 1991, s. $3^{*}-4^{*}$ (=LM VI). Na podanych stronach znajdują się również sugestie dotyczące drugiego czytania i Ewangelii. 


\section{LUD ZGROMADZONY PRZED BOGIEM - ZAPOWIEDŹ KOŚCIOŁA W STARYM TESTAMENCIE}

Jako pierwsze czytanie w liturgii obrzędów poświęcenia nowego kościoła rubryki zalecają, aby wziąć perykopę z Księgi Nehemiasza $(8,1-$ -4a.5-6.8-10. Po niej należy śpiewać Psalm 18B,8-9.10.15 wraz z refrenem: „Słowa Twe, Panie, są duchem i życiem”6.

Autor Księgi Nehemiasza opisuje zgromadzenie Izraela w dniu Pańskim dla odczytania Prawa ${ }^{7}$. Po powrocie Izraelitów z niewoli babilońskiej odbywało się ono na placu przed Bramą Wodną. Egzegeci przypuszczają, że chodzi o bardzo przestronny taras pałacu królewskiego, który w tamtym czasie nie był jeszcze zbudowany. Jeśli ta teza jest słuszna, plac ten graniczyłby w swej północnej części z terenem świątyni i można by go utożsamiać z placem przed Domem Bożym. Zgromadzenie Izraela, w którym odczytywano Prawo, byłoby zatem zgromadzeniem liturgicznym, którego ceremoniał zaczerpnięto z powszechnie znanych zebrań liturgicznych w synagogach babilońskich ${ }^{8}$.

Akcja liturgiczna rozpoczynała się od wstąpienia Ezdrasza na podwyższenie, od rozwinięcia zwoju Księgi Prawa i jego odczytania. Lud słuchał słów księgi w postawie stojącej, aby wyrazić cześć dla słowa Bożego (zob. 1Kor 1,28-31) i swoją gotowość do realizacji zaleceń Bożych (zob. Dn 1,4; 5,19). Przed odczytaniem Prawa odmawiano krótką modlitwę pochwalną, którą lud potwierdzał dwukrotnym zawołaniem: Amen. Tej odpowiedzi towarzyszyło również wzniesienie rąk i oddanie pokłonu do ziemi w postawie klęczącej. Następnie Ezdrasz wypowiada słowa: „radość w Jahwe jest ostoją waszą", zachęcając w ten sposób do radosnej uczty, podczas której zebrany lud mógł spożywać tłuste potrawy i pić słodkie wino, gdyż ten dzień był poświęcony Bogu .

${ }^{6}$ OPKiO, s. 49, nr 53.

7 Według dawnego zwyczaju w zebraniu, na, którym odczytywano Prawo, brały udział także niewiasty i dzieci. O udziale tych ostatnich decydował wiek, w którym dziecko pojmuje to, co mu się przedstawia. Zob. H. Langkammer, Księga Ezdrasza - Nehemiasza. Wstęp, przekład z oryginału, komentarz, eskursy, t. II, Poznań-Warszawa 1971, s. 252.

8 Por. J. Drozd, Księga Nehemiasza, w: Pismo Święte Starego i Nowego Testamentu, red. M. Peter, t. I. Poznań 2000, s. 845.

${ }^{9} \mathrm{~W}$ tym miejscu po raz pierwszy w Starym Testamencie jest mowa o ambonie. 
Izraelici po zawarciu przymierza z Bogiem stali się narodem wybranym, czyli ludem Bożym ( por. Wj 19,6-7). Od tego momentu Izrael stał się ludem świętym poświęconym Bogu i dla Niego przeznaczonym. Stał się Jego wyłączną własnością i dziedzictwem (por. Pp 7,6; 14,2; Jer 2,3; Oz 2) ${ }^{10}$. W odczytanej perykopie widzimy lud zgromadzony przed Bogiem, aby słuchać Jego Prawa. Obok przywilejów lud ten miał świadomość obowiązków wobec Boga, które wyrażały się w uznawaniu Jahwe za jedynego Boga, przestrzeganiu Jego przykazań, słuchania pouczeń. Obowiązkiem był również udział w kulcie liturgicznym sprawowanym przez całe zgromadzenie Izraela, będącego podmiotem sprawowanej liturgii, a nie przedmiotem, dla którego się odprawia. Przyjmując zasadę, że Stary Testament był obietnicą i zapowiedzią pełni czasów zrealizowanej w Jezusie i przez Jezusa, możemy powiedzieć, że w tej perykopie znajdujemy symboliczne wyobrażenie Kościoła jako ludu Bożego. Chrześcijanie, czując się dziedzicami obietnic i przywilejów danych przez Boga staremu ludowi, nazywali siebie nowym ludem Bożym. Elementem łączącym oba Testamenty jest eschatologia prorocka, która zapowiada i opisuje już z góry lud Boży Nowego Przymierza ${ }^{11}$.

Lud stojący przed Jahwe i słuchający Jego słowa tworzy zgromadzenie liturgiczne. To kolejne wyobrażenie symboliczne zapowiadające Kościół. Stary Testament termin zgromadzenie określa trzema hebrajskimi słowami: edah, qahal i miqra ${ }^{12}$. Zgromadzenie liturgiczne Ezdrasza (Ezd $3,1-13$; 10,1-17) określone jest hebrajskim qahal, tłumaczonym przez Septuagintę jako greckie słowo ' $\varepsilon \kappa \kappa \lambda \eta \sigma i \alpha^{13}$. Natomiast w języku łacińskim słowo ecclesia oznacza Kościół jako zgromadzenie ludu, zebranie się ludzi

Podwyższenie to używane było również w synagogach do czytania lekcji i wygłaszania kazań. Podkreślało ono ważność chwili. Zob. H. Langkammer, Księga Ezdrasza - Nehemiasza, dz. cyt., s. 253.

10 Por. M. Cimosa, Popolo. Popoli, w: Nuovo dizionario di teologia biblica, red. P. Rossano, G. Ravasi, A. Girlanda, Milano 1988, s. 1189.

11 Por. P. Grelot, Lud, w: Słownik teologii biblijnej, red. X. Leon-Dufour, Poznań 1990, s. 425-426.

12 Zob. H.J. Sobeczko, Zgromadzeni w imię Pana, teologia znaku zgromadzenia liturgicznego, Opole 1999, s. 64.

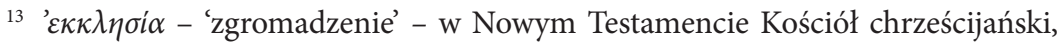
w: Słownik grecko-polski, red. Z. Abramowicz, t. II, Warszawa 1960, s. 64. 
tworzących wspólnotę wierzących lub miejsce zgromadzenia się wierzących dla oddania czci Bogu.

W strukturze zgromadzenia liturgicznego Ezdrasza ważnym elementem była uczta spożywana w atmosferze radości i dziękczynienia. Możemy w niej wyróżnić poszczególne elementy: zwołanie zgromadzenia, intronizację Księgi (otwarcie), doksologię wstępną, proklamację Słowa Bożego (Prawo), komentarz (homilia), ucztę, dzielenie się z biednymi (rodzaj agapy). Elementy te można uważać za zapowiedź zgromadzeń liturgicznych Kościoła jako prawdziwej epifanii, w której żyje i działa cały Chrystus - Głowa i członki ${ }^{14}$.

Według posoborowego nauczania Kościoła zgromadzeniem liturgicznym nazywamy zebranie się razem ochrzczonych i wierzących dla sprawowania czynności liturgicznych pod przewodnictwem przedstawiciela hierarchii kościelnej. Jest to wspólnota hierarchicznie uporządkowana, w której każdy człowiek ma do spełnienia określone zadania, wynikające z przyjętych święceń, posług, czy naturalnych uzdolnień i charyzmatów ${ }^{15}$.

Konkretne zgromadzenie liturgiczne zebrane na liturgii w świątyni parafialnej stanowi cząstkę Kościoła powszechnego i jest jego symbolem. To bardzo ważne stwierdzenie, ponieważ uświadamia, że każda wspólnota zgromadzona na liturgii objawia i urzeczywistnia cały Kościół. Podobnie jak Kościół jest wspólnotą hierarchicznie uporządkowaną. Zgromadzenie liturgiczne jest także znakiem obecności Chrystusa w swoim Kościele i spełnieniem Jego obietnicy: „Gdzie dwaj, albo trzej zbiorą się w imię moje, będę pośród nich obecny” (Mt 18,20) ${ }^{16}$.

Starotestamentalne perykopy są bardzo wyrazistą zapowiedzią Kościoła Chrystusowego oraz jego istoty. Kościół Nowego Przymierza stanie się nowym ludem Bożym i duchową świątynią. Należy także podkreślić istotny element, którym jest zgromadzenie kultyczne, stanowiące serce Kościoła, zbudowanego przez Chrystusa na fundamencie apostołów i proroków. Zapowiedzi nowej rzeczywistości jako obietnica i cień są obec-

${ }_{14}$ Por. H. J. Sobeczko, Zgromadzeni w imię Pana, teologia znaku zgromadzenia liturgicznego, dz. cyt., s. 63, 72-73.

${ }_{15}$ Por. H.J. Sobeczko. Zgromadzenie celebruje liturgię, w: Msza Święta - rozumieć, aby lepiej uczestniczyć. Wykład liturgii Mszy, red. J. Hadalski, Poznań 2013, s. 87-91.

16 Por. J. Grześkowiak, Oto wielka tajemnica wiary, Poznań 1987, s. 39-42. 
ne w perykopach biblijnych czytanych jako pierwsze czytanie w liturgii poświęcenia kościoła.

\section{OBRAZY KOŚCIOŁA W PISMACH PAWŁOWYCH I APOKALIPSIE}

Obrzęd poświęcenia nowego kościoła daje bogatą możliwość wyboru drugiego czytania, które winno być wzięte z Nowego Testamentu. Lekcjonarz mszalny podaje następujące czytania do wyboru w okresie zwykłym, w święta i wspomnienia: 1Kor 3,3b-11.16-17; Ef 2,19-22; Hbr 12,18-19.22-24; 1P 2,4-9. Natomiast w okresie wielkanocnym można wziąć perykopy Ap 21,1-5a lub Ap 21,9b-14 ${ }^{17}$.

\section{KOŚCIÓł ClAŁEM CHRYSTUSA I NOWYM LUDEM BOŻYM}

Święty Paweł w Liście do Efezjan nazywa Kościół Ciałem Chrystusa (zob. Ef 1,21-22). Mówi on o Chrystusie jako Głowie ciała Kościoła ${ }^{18}$. Wszyscy ludzie są wezwani przez Chrystusa, aby przez chrzest stanowili jeden Kościół, który staje się ostatecznie jedyną świątynią - Ciałem Chrystusa, żywym organizmem, w którym poszczególne członki uczestniczą we wspólnym dobru ${ }^{19}$. W tym kontekście Kościół, rozumiany jako Ciało Chrystusa, które w sposób mistyczny tworzą wszyscy wierni, jest samym Chrystusem. W nich przeżywa On swoje misterium Wcielenia, śmierci i zmartwychwstania. W tym sensie można o Kościele powiedzieć, że jako Ciało Chrystusa jest on także nowym ludem Bożym, który otrzymuje nowe wartości zbawcze ${ }^{20}$.

17 Zob. LM VI, s. $4^{*}$.

18 "Ciało” (soma) w Nowym Testamencie ma znaczenie teologiczne. Wskazuje ono przede wszystkim na jedność. „Ciało Chrystusa” w odniesieniu do Kościoła określa rodzaj związków, które zachodzą między ludźmi a Chrystusem i między nimi samymi w zespoleniu z Chrystusem. W Nowym Testamencie ma trzy znaczenia: indywidualne ciało Jezusa, Eucharystię i Kościół. Zob. E. Ozorowski, Kościół, dz. cyt., s. 54.

19 Por. A. Jankowski, Listy więzienne świętego Pawła. Wstęp - przekład z oryginału - komentarz, Poznań 1962, t. VIII, s. 412-415. Sprawę uczestnictwa poszczególnych członków szerzej wyjaśnia m.in. E. Ozorowski, Kościót, dz. cyt., s. 67-68.

20 Por. H. Langkammer, Nauka św. Pawła o Kościele, w: Kościół w świetle Biblii, red. J. Szlaga, Lublin 1984, s. 85. 
Lud Boży w Starym Testamencie tworzy się poprzez przymierze zawarte na górze Synaj pomiędzy Bogiem a Izraelem. W Nowym Testamencie nowym ludem Bożym, drugim duchowym Izraelem jest Kościół, stworzony przez Krew Chrystusa. Do tego nowego ludu Bożego człowiek wchodzi przez chrzest i wiarę. Żaden chrześcijanin nie pozostaje w Kościele odosobniony, ale jest wcielony do wspólnoty nowego ludu Bożego ${ }^{21}$. Kościół jako nowy lud Boży staje się przeciwieństwem starego ludu, w którym poganie byli traktowani jako obywatele drugiej kategorii i obcy. Kościół przyjmuje pogan przez chrzest i nie traktuje ich jako obcych lub obywateli drugiej kategorii ${ }^{22}$.

Autor Listu do Hebrajczyków podkreśla, że chrześcijanie nie przystąpili do Góry Synaj, która symbolizuje Stare Przymierze, ale do jej przeciwieństwa, czyli do Góry Syjon - symbolu Nowego Przymierza. Góra Syjon to góra pokoju i duchowości. Na niej chrześcijanie spotykają się z Bogiem, otrzymują zbawienie i życie wieczne (por. Hbr 12,18-19.22$-24)^{23}$. Autor listu ukazuje również nieaktualność pierwszego zgromadzenia oraz znamienną cechę drugiego, jaką jest przystępność i otwartość Bożej rzeczywistości dla wiernych. Uczestniczą oni w kulcie, jaki oddaje Bogu w niebieskim sanktuarium niezliczona liczba aniołów, stanowiąc uroczyste zebranie (zob. Dn 7,10) ${ }^{24}$. Nowy lud Boży jest więc wspólnotą kultową, która postępuje nie tylko duchowo, ale i religijnie. Wierni idący do świątyni w procesji kultycznej łączą się w miłości. Są to aspekty, które szerzej ukazują charakter eschatologiczny i wspólnotowy Kościoła ${ }^{25}$. W Nowym Testamencie miejsce starego ludu Bożego zajął nowy, tworzony przez chrześcijan, którzy uczestniczą w kapłaństwie Chrystusowym, stojąc przed Bogiem i mając do Niego bezpośredni dostęp. Wszyscy chrześci-

${ }^{21}$ Por. W. Kreft, Kościół jako zgromadzenie liturgiczne w Liście do Hebrajczyków, RBL 4 (1973), s. 188-193.

22 Por. A. Jankowski, Listy więzienne świętego Pawła, dz. cyt., s. 410.

${ }^{23}$ LM, s. 27*; Zob. S. Łach, List do Hebrajczyków. Wstęp - przekład z oryginału - komentarz - eskursy, t. X, Poznań 1959, s. 280. Nazwa Syjon stanowi także techniczny termin na oznaczenie wzgórza świątynnego i samej świątyni.

${ }^{24}$ Por. K. Romaniuk, A. Jankowski, L. Stachowiak, Komentarz praktyczny do Nowego Testamentu, t. II, Poznań-Kraków 1999, s. 472-473.

${ }_{25}$ Zob. W. Kreft, Kościół jako zgromadzenie liturgiczne w Liście do Hebrajczyków, dz. cyt., s. 193. 
janie składają duchowe ofiary, głosząc radosną nowinę o wielkości Boga w Jezusie Chrystusie ${ }^{26}$.

Kościół jest idealnym nowym ludem Bożym wybranym przez Boga. Jego członkowie zostali wykupieni na własność Boga przez bezcenną Krew Jezusa Chrystusa przelaną na krzyżu. Oznacza to, że nie może on postępować tak, jak chce, ale jak nakazuje Bóg, który powołuje każdego $\mathrm{z}$ wiernych, a z wszystkich razem utworzy sobie naród - Kościół, nazywany nowym ludem Bożym. Kościół jest dynamiczny, ponieważ żyje i wędruje jak Lud Boży Starego Testamentu do ostatecznego celu wyznaczonego przez Boga ${ }^{27}$.

\section{KOŚCIÓł JAKO DUCHOWA ŚWIĄTYNIA}

Kolejne wyobrażenie Kościoła znajdujemy w Liście świętego Pawła Apostoła do Efezjan, gdzie jest on ukazany jako „duchowa świątynia”. Apostoł Paweł wskazuje tutaj problem jedności Kościoła jako budowli, nawiązując do zwartej społeczności Izraela, względem której obcymi byli poganie. W drugim rozdziale listu do Efezjan w wierszu 19 wraca do tej myśli, zaliczając już dawniejszych pogan do owej zamkniętej społeczności, a w wierszu 22 stwierdza, że odtąd istnieje jeden Kościół składający się zarówno z Żydów, jak i pogan ${ }^{28}$. W tym kontekście Kościół zostaje określony jako budowla oparta na fundamencie apostołów i proroków. Zmierza on ku ostatecznemu celowi, którym jest świątynia w Panu, w której wszyscy wierni złączeni są w jedną budowlę ${ }^{29}$. Dlatego też Boga nie można wiązać z jedną konkretną świątynią - budowlą ${ }^{30}$.

Święty Szczepan w swojej mowie przed ukamienowaniem (zob. Dz 7,44-50) wspomina zamiar zbudowania przez króla Dawida świątyni

${ }^{26}$ Zob. K. Romaniuk, A. Jankowski, L. Stachowiak, Komentarz praktyczny do Nowego Testamentu, t. II, dz. cyt., s. 515.

${ }_{27}$ Zob. W. Kreft. Kościół jako zgromadzenie liturgiczne w Liście do Hebrajczyków, dz. cyt., s. 190-191.

28 Por. H. Langkammer. Nauka św. Pawła o Kościele, dz. cyt., s. 103.

29 Por. tamże s. 103-104. Zob. także A. Jankowski, Dwie świątynie Ducha Świętego według listów Pawłowych, RBL1(1988)20.

30 Zob. B. Nadolski, Wprowadzenie do liturgii, Kraków 2004, s. 195. 
dla Jahwe, urzeczywistniony dopiero przez jego syna Salomona. Zauważa jednak, że Najwyższy nie mieszka w dziełach rąk ludzkich (zob. Dz 7,48), choćby nawet tak wspaniałych jak świątynia Salomona. Zrywa tym samym ze zbyt materialną kategorią kultu Boga. Poparciem słów św. Szczepana są dzieje Izraela (zob. Dz 6,13-56). Świadczą one o tym, że Bogu oddawano cześć, gdy jeszcze nie było świątyni. Jego kultu nie wiązano początkowo z określonym miejscem, a Boga można było wielbić nie tylko w świątyniach wznoszonych przez ludzi. Mówił o tym również Jezus w rozmowie z Samarytanką przy studni Jakubowej (zob. J 4,16-24) ${ }^{31}$.

Analogiczną problematykę porusza także św. Paweł w Liście do Koryntian, pisząc, iż duchową świątynią są wszyscy chrześcijanie, czyli każdy ochrzczony. Zajęła ona miejsce jedynej dla całego Izraela świątyni jerozolimskiej wzniesionej ludzką ręką. Tą świątynią jest cała społeczność Kościoła oraz wnętrze każdego człowieka, gdyż w nim mieszka Duch Święty (1Kor 3,16-17) ${ }^{32}$. Dla św. Pawła duchową świątynią jest Kościół, zespolony przez Jezusa, jako kamień węgielny, a budowany przez Boga za sprawą Ducha Świętego na fundamencie apostołów i proroków, a szczególnie na Piotrze - Opoce ${ }^{33}$. W świątyni tej znajdą się również kapłani, którzy korzystając z przywilejów Jezusa, razem z nim będą składali duchowe ofiary miłe Bogu i razem z Chrystusem będą sprawowali w niej duchowa służbę Bożą, wykonując święte kapłaństwo ${ }^{34}$.

Obraz duchowej świątyni ukazuje także św. Piotr w Pierwszym Liście (1P 2,4-6). Pisze on, że wszyscy wierni, będąc blisko Pana, zostaną wzięci jako żywe kamienie do budowy świątyni. Jezus Chrystus jest drogocennym kamieniem wybranym przez Boga, którego nikt nie może zastąpić. Jest głowica węgła tej świątyni, nadającą jedność poszczególnym kamieniom. Chrześcijanie więc, którzy przybliżają się do Chrystusa jako żywego kamienia, staną się do Niego podobni. Będą również żywymi kamieniami, które ustawicznie czerpią nadprzyrodzone życie od swego

${ }^{31}$ Por. R. Andrzejewski, F. Jóźwiak, Dzieje Apostolskie, Poznań 1998, s. 38-39; zob. także. B. Nadolski, Wprowadzenie do liturgii, dz. cyt., s. 194

32 Por. K. Romaniuk, A. Jankowski, L. Stachowiak, Komentarz praktyczny do Nowego Testamentu, t. II, dz. cyt., s. 116.

33 Tamże, s. 514.

34 Tamże. 
Zbawiciela, przyczyniając się swoim życiem do wzrostu duchowej świątyni na chwałę Ojcu ${ }^{35}$.

W Księdze Apokalipsy fundamentem duchowej świątyni, którą stanowi święta społeczność Nowego Jeruzalem, są wybrani pomocnicy Boży, czyli apostołowie i prorocy. Kościól jest zatem ziemskim odbiciem Nowego Jeruzalem, Oblubienicy Chrystusa, której opis znajdujemy w Apokalipsie św. Jana (zob. Ap 21,1-3;9b-24). Autor Apokalipsy porównuje ludzkość do oblubienicy Baranka, którą jest Kościół - święte miasto Jeruzalem (zob. Ap 21, 1-11). Miłość oblubieńcza i dziewicza, jaką ukazuje Apostoł Jan, są najważniejszymi cechami Kościoła. Przypominają one stan, w jakim znajdowali się pierwsi rodzice $\mathrm{w}$ raju oraz dziewicze poczęcie Jezusa Chrystusa. Jednocześnie zapowiadają wypełnienie się obietnic królestwa niebieskiego. Oznacza to, że żaden człowiek w Kościele nie jest obojętny Chrystusowi, który wszystkich kocha miłością oblubieńczą ${ }^{36}$.

Święty Jan opisuje piękno niebieskiego Jeruzalem, które oznacza miejsce oraz ludzi w nim mieszkających. Bogactwo Nowego Jeruzalem opisywanego przez Jana może przypominać świetność świątyni Heroda. Autor oznajmia, że w tym mieście przebywa chwała Boża, która jest znakiem Jego obecności. Nowe Jeruzalem jako oblubienica będzie miała udział w chwale tej świątyni. Chwała Boża już dziś przysługuje doczesnemu Kościołowi, jako że ma moc przemieniać wszystkich wiernych. Obraz Jerozolimy jako miasta - Oblubienicy mówi o jego izraelskich korzeniach, o nowych więzach z Bogiem i ludźmi. Jako nowe miasto, Jerozolima będzie miała otwarte bramy, gdyż wszyscy jej mieszkańcy będą sobie równi, posiadając status obywateli. Wyraża się tu myśl, że zbawienie ze swej istoty ma charakter społeczny i wspólnotowy ${ }^{37}$.

Stara świątynia jerozolimska oddzielała kapłanów od ludzi świeckich, a w Nowym Jeruzalem - Oblubienicy nie ma świątyni, gdyż sam Bóg zamieszkał ze swym ludem. Świątynią Boga jest całe miasto, a jego

35 Por. F. Gryglewicz, Listy katolickie; Wstęp - przekład z oryginału - komentarz, t. XI, Poznań 1989, s. 196-197.

${ }^{36}$ Por. E. Ozorowski, Kościót, dz. cyt., s. 61. Do tego obrazu miłości bardzo często uciekali się wielcy mistycy, m.in. św. Jan od Krzyża, Dzieła, Kraków 1998, s. 155-156.

37 Tamże s. 633. 
wiecznym źródłem światła i życia jest Bóg - źródło wszelkiego życia ${ }^{38}$. Święty Jan Apostoł w opisie Nowego Jeruzalem - Oblubienicy posługuje się danymi z obu Testamentów, ukazując jedność zbawczego planu Boga Kościół jako Nowy Izrael ${ }^{39}$. Kojarzy on dwanaście bram Jeruzalem z dwunastoma pokoleniami Izraela, ukazując tutaj symbol powszechności Kościoła (zob. Ap 21,12-13). Podkreśla zarazem ciągłość pomiędzy dwunastoma pokoleniami Starego Testamentu a dwunastoma apostołami z Nowego Testamentu, ukazując Kościół w czasie i wieczności jako apostolski w swym pochodzeniu (zob. Ap 21,14) ${ }^{40}$.

Choć mamy tutaj aluzję do świątyni rozumianej jako budowla wzniesiona przez ludzi, to jednak trzeba tu widzieć bardziej aspekt duchowy niż materialny. Budowniczym prawdziwej świątyni, nowego miasta - Niebieskiego Jeruzalem jest Bóg. Wszystkie perykopy biblijne przeznaczone do wyboru na liturgię poświęcenia nowego kościoła bardzo mocno akcentują wymiar duchowy. Ziemska budowla kościoła wskazuje na głębokie rzeczywistości duchowe, które w niej się kryją. Kościół zbudowany na ziemi przez ludzi staje się czytelnym znakiem działania Boga oraz wskazuje człowiekowi drogę do Boga i do życia wiecznego.

\section{KOŚCIÓł ZBUDOWANY NA SKALE - EWANGELIA}

Rubryki Lekcjonarza mszalnego przewidują, aby w dniu poświęcenia nowego kościoła odczytywano perykopę z Ewangelii według św. Mateusza (Mt 16,13-19) ${ }^{41}$. W tekście tym znajdujemy wypowiedź Chrystusa o Piotrze jako opoce Kościoła: „Otóż i Ja tobie powiadam: Ty jesteś Piotr, czyli Skała i na tej Skale zbuduję Kościół mój, a bramy piekielne go nie przemogą" (Mt 16,18). Pod Cezareą Filipową, po wyznaniu wiary przez Szymona, Jezus zmienia jego pierwotne imię, nadając mu nowe -

38 Por. E.A. Kuckerlkorn, M.D. Mateos, T. Kraft, Apokalipsa św. Jana, w: Międzynarodowy Komentarz do Pisma Świętego, red. W. Chrostowski, Warszawa 2000, s. 1703.

39 Por. A. Jankowski, Apokalipsa świętego Jana; Wstęp - przekład z oryginału komentarz, t. XII, Poznań 1959, s. 278.

40 Por. K. Romaniuk, A. Jankowski, L. Stachowiak, Komentarz praktyczny do Nowego Testamentu, t. II, dz. cyt., s. 672.

${ }^{41}$ LM, s. $4^{\star}$ i $30^{\star}$. 
Piotr (greckie: $\pi \varepsilon \tau \rho o \varsigma ; \pi \varepsilon \tau \rho \alpha$; aramejskie: kêfā = opoka, skała). Zmiana imienia miała znaczenie symboliczne i wyrażała zależność osoby, która imię otrzymywała, od tego, który je nadawał. Odtąd, z woli Jezusa, Piotr będzie opoką jako apostoł, a nie jako osoba prywatna, nosząca dotąd imię Szymon. Wiara Piotra w mesjańską godność Jezusa stanowić będzie trwały fundament, na którym Jezus zbuduje swój Kościół ${ }^{42}$. Kościół jako społeczność wszystkich wierzących w Jezusa, gdziekolwiek by wierzący się znajdowali i kiedykolwiek by żyli, będzie zbudowany nie na Piotrze jako człowieku, ale na wierze i prawdzie wyrażonej przez Niego o Jezusie jako synu Boga Żywego. Chrystus jest kamieniem węgielnym, który łączy dwa narody w jednej wierze, w jednej nadziei i w jednej miłości, jak dwie ściany. Pierwszym narodem są przychodzący od obrzezanych - wierzący Judejczycy, a drugim przychodzący od nieobrzezanych, czyli wierzący poganie. Według nauk Jezusa kamieniami są również pozostali apostołowie, spośród których jako pierwszy i najważniejszy zawsze będzie Piotr ${ }^{43}$.

Grę słów: „Ty jesteś Piotr i na tej opoce zbuduję Kościół mój”

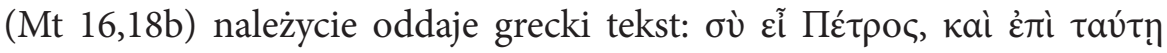

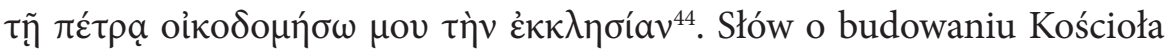
nie można odnosić do żadnej innej skały, lecz tylko do osoby Piotra, będącego skałą i wyrażającą ideę siły oraz trwałości ${ }^{45}$. Przez wiarę Piotr ma być protoplastą nowego ludu Bożego, nowego Izraela, podobnie jak Abraham był protoplastą - lub jak mówi Prorok - skałą starego Izraela ${ }^{46}$. Piotr jest tym, który zapewnia Kościołowi trwałość, ład, jedność i siłę. On jest mocnym fundamentem, na którym Jezus buduje duchową świątynię dla Boga z żywych kamieni ${ }^{47}$.

${ }^{42}$ Por. E. Dąbrowski, Ewangelia według świętego Mateusza; Wstęp - przekład z oryginału - komentarz, t. III, Poznań-Warszawa 1979, s. 248-249.

${ }^{43}$ Por. M. Jakimiuk, H. Gabriel, J. Misiejuk, Komentarz Świętych Ojców do Ewangelii według Św. Mateusza, Białystok 2000, s. 503.

${ }^{44}$ Grecko-polski Nowy Testament. Wydanie interlinearne $z$ kodami gramatycznymi, R. Popowski, M. Wojciechowski (tłum.), Warszawa 1997.

${ }_{45}$ Por. K. Romaniuk, A. Jankowski, L. Stachowiak, Komentarz praktyczny do Nowego Testamentu, t. I, dz. cyt., s. 97.

${ }^{46}$ Por. E. Dąbrowski, Ewangelia według świętego Mateusza, dz. cyt., s. 249.

47 Por. K. Romaniuk, A. Jankowski, L. Stachowiak, Komentarz praktyczny do Nowego Testamentu, t. I, dz. cyt., s. 98. 


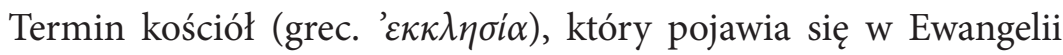
według św. Mateusza, jest określeniem wspólnoty mesjańskiej nowego Przymierza zakładanej przez Jezusa. W czasach Chrystusa ten termin znany był jako hebrajskie qahal, gdzie w Starym Testamencie oznaczano nim wspólnotę zmierzającą do Ziemi Obiecanej. Po zawarciu Przymierza na Synaju terminem tym określano lud Boży zebrany w przybytku na liturgiczną służbę Bożą - było to zgromadzenie Jahwe (zob. Lb 16,3; 20,4; Pwt 23,2-3; Ps 22 (21),13.26; 35 (34),18). Między starotestamentalną wspólnotą określaną terminem qahal a wspólnotą budowaną na Piotrze istnieje zasadnicza różnica, wyrażająca się w tym, że Jezus tę wspólnotę określa mianem Kościół mój ${ }^{48}$.

Wzmianka o bramach piekielnych, które nie mogą zniszczyć Kościoła (Mt 16,18b), jest już tylko wysnuciem wniosku, że Piotr jako fundament będzie źródłem trwałości całego Kościoła ${ }^{49}$. Kościół zbudowany na Piotrze, istniejąc na ziemi, stanowi zapowiedź Królestwa niebieskiego. W tym kontekście trzeba go widzieć jako instytucję zbawczą, a nie społeczną ${ }^{50}$.

W Ewangelii według św. Mateusza możemy znaleźć symboliczne wyobrażenie Kościoła jako duchowej świątyni budowanej przez Chrystusa na skale, jaką jest Piotr. Świątynia ta zbudowana jest z żywych kamieni, którymi są judeochrześcijanie i etnochrześcijanie. Kościół staje się wspólnotą otwartą dla wszystkich ludzi. Bramą do Kościoła jest wiara w Jezusa Chrystusa i przyjęty chrzest. Jest on miejscem, w którym jest obecny i zbawczo działa Jezus Chrystus. Jezus przez swoją śmierć i zmartwychwstanie oczyszcza Kościół i utożsamia się z nim. Jego ciało stało się prawdziwą świątynią, w której prawdziwi czciciele oddają cześć Bogu w duchu i w prawdzie. Te rzeczywistości ukazują perykopy przewidziane na rocznicę poświęcenia kościoła (por. J 2,13-22; J 4,4.19-24) ${ }^{51}$.

48 Por. E. Dąbrowski, Ewangelia według świętego Mateusza, dz. cyt., s. 249.

49 Por. K. Romaniuk, A. Jankowski, L. Stachowiak, Komentarz praktyczny do Nowego Testamentu, t. I, s. 98.

${ }^{50}$ Por. E. Dąbrowski, Ewangelia według świętego Mateusza, dz. cyt., s. 250.

${ }^{51}$ LM, s. $32^{\star}-33^{*}$. 


\section{ZAKOŃCZENIE}

Treść biblijnych perykop przeznaczonych do proklamowania w liturgii poświęcenia nowego kościoła jest bardzo bogata i zawiera w sobie wymowną symbolikę teologiczną pokazującą rzeczywistość Kościoła. Przeprowadzona egzegeza czytań ze Starego i Nowego Testamentu pozwala stwierdzić, że pomimo swych wielu symbolicznych wyobrażeń, Kościół jest jeden dla wszystkich wierzących, tak jak niegdyś świątynia jerozolimska była jedynym miejscem obecności Boga dla całego Izraela. Kościół jest niezwykłą budowlą, Oblubienica Chrystusa, odbiciem niebieskiej Jerozolimy, o której pisał św. Jan w Apokalipsie (zob. Ap 21,2-3;9b-19).

Kościół łączy chrześcijańską ideę wspólnoty wybranych i ciała mistycznego z ideą świątyni żydowskiej, ukazując ciągłość Starego i Nowego Testamentu, dawnej i nowej świątyni. Potwierdza to tradycja sięgająca najdawniejszej starożytności, której dowodem mogą być słowa św. Klemensa Rzymskiego z Traktatu o Boskim oficjum: Bóg sam wskazał swoja najwyższa wola miejsce, gdzie ten święty obrządek winien być celebrowany i tych, którzy powinni go celebrowaćs2.

Poświęcenie nowego kościoła i obchodzenie rocznicy tego wydarzenia winno stać się jednym z najważniejszych świąt w życiu każdej parafii. Wydaje się, że dziś uroczyście obchodzi się sam dzień poświęcenia kościoła, natomiast kolejne rocznice tego bardzo ważnego wydarzenia są jakby zapomniane i niedoceniane przez wiernych. Stąd rodzi się potrzeba pogłębionej katechezy o znaczeniu budynku kościelnego dla wiernych oraz pogłębionej świadomości, że oni jako wspólnota tworzą prawdziwy Chrystusowy Kościół zbudowany na fundamencie proroków i apostołów. Przez chrzest wszyscy zostali włączeni do Kościoła, który jest Mistycznym Ciałem Jezusa Chrystusa i duchową świątynią. Głębsza świadomość rozumienia przynależności i istoty Kościoła może wiernym pomóc bardziej zaangażować się w życie konkretnej wspólnoty parafialnej, która jest obrazem całego Kościoła.

${ }^{52}$ Klemens Rzymski, Traktat o Boskim oficjum, cyt. za: J. Hani, Symbolika świqtyni chrześcijańskiej, Karków 1994, s. 21. 
Streszczenie. Artykuł przedstawia i omawia teologię symbolicznych wyobrażeń Kościoła w czytaniach biblijnych przewidzianych na liturgiczny obrzęd poświęcenia nowego Kościoła. Każda z tych nazw i metafor ma swoją szczególną treść, którą trzeba właściwie zrozumieć, aby odkryć tajemnicę Chrystusowego Kościoła, którego znakiem jest każdy kościół wybudowany przez ludzi na ziemi. Podstawowym źródłem dla artykułu są perykopy biblijne przeznaczone na dzień poświęcenia kościoła. Stary Testament, który zapowiada „pełnię czasów” zrealizowaną w Chrystusie, pokazuje Izraelitów jako lud zgromadzony przed Bogiem. Stają oni przed Bogiem w zgromadzeniu kultycznym, aby słuchać słowa Bożego. Ten lud jest zapowiedzią nowego ludu Bożego, który zgromadził wokół siebie Jezus Chrystus. Wszyscy wierzący w Chrystusa i ochrzczeni w Jego imię zostają włączeni do nowego ludu Bożego i stają się cząstką Mistycznego Ciała Chrystusa. Te dwa terminy określają w Nowym Testamencie wspólnotę Kościoła. Dzięki darowi Ducha Świętego Kościół jest świątynią duchową powołaną do składania duchowych ofiar Bogu przez Jezusa w Duchu Świętym. Kościół jest rzeczywistością trwałą, ponieważ jest zbudowany na fundamencie apostołów i proroków, spośród których na pierwszym miejscu jest św. Piotr i jego następcy. Bogactwo treści teologicznych zawartych w lekturach biblijnych stwarza okazję do pogłębionej katechezy dotyczącej istoty Kościoła, a to z kolei winno prowadzić wiernych do bardziej aktywnego zaangażowania się w życie konkretnej wspólnoty parafialnej, która jest obrazem Kościoła powszechnego.

Słowa kluczowe: Kościół; poświęcenie kościoła; nowy lud Boży; Mistyczne Ciało Chrystusa; świątynia; św. Piotr.

Abstract. The Symbolic Image of the Church in the Biblical Pericopes Proclaimed in the Liturgy of the Rite of Dedication of a Church. The article presents and elaborates on the theology underlying the symbolic images of the Church in the biblical readings foreseen for the liturgical rite of the dedication of a new church. Each of these images and metaphors possesses its own particular content which needs to be properly understood in order to discover the mystery of Christ's Church signified by every church built by men on earth. The biblical pericopes assigned to the day of the dedication of the church are the main point of departure for this article. The Old Testament which foretells the "fullness of time" as realized in Christ depicts the Israelites as a people gathered before God. They stand before the Lord in a cultic gathering in order to listen to the word of God. They foreshadow the new people of God whom Jesus Christ gathered around Himself. All of Christ's followers and those baptized in His name are grafted onto the new People of God and become part of the Mystical Body of Christ. These two terms refer to the community of the Church in the New Testament. Thanks to the gift of the Holy Spirit the Church is a spiritual temple called to offer spiritual gifts to God through Jesus in the Holy Spirit. The Church is an enduring reality, because it is founded upon the Apostles and prophets, among whom Saint Peter and his successors have a pride of place. The richness of the biblical readings' theological content becomes an opportunity for a deepened catechesis about the Church's nature. This, in turn, should lead the faithful 
to a more active participation in the life of a concrete parish community which is an image of the Universal Church.

Key words: Church;dedication of a church; word of God; new people of God; Mystical Body of Christ; temple; Saint Peter.

\section{BIBLIOGRAFIA}

Andrzejewski R., Jóźwiak F., Dzieje Apostolskie, Poznań 1998.

Cimosa M., Popolo. Popoli, w: Nuovo dizionario di teologia biblica, red. P. Rossano, G. Ravasi, A. Girlanda, Milano 1988, s. 1189-1202.

Dąbrowski E., Ewangelia według świętego Mateusza; Wstęp - przekład z oryginału - komentarz, t. III, Poznań-Warszawa 1979.

Drozd J., Księga Nehemiasza, w: Pismo Święte Starego i Nowego Testamentu, red. M. Peter, t. I, Poznań 2000.

Grecko-polski Nowy Testament. Wydanie interlinearne z kodami gramatycznymi, tłum. R. Popowski, M. Wojciechowski, Warszawa 1997.

Grelot P., Lud, w: Słownik teologii biblijnej, red. X. Leon-Dufour, Poznań 1990, s. 425-435. Gryglewicz F., Listy katolickie; Wstęp - przekład z oryginału - komentarz, t. XI, Poznań 1989.

Grześkowiak J., Oto wielka tajemnica wiary, Poznań 1987.

Hani J., Symbolika świątyni chrześcijańskiej, Kraków 1994.

Jakimiuk M., Gabriel H., Misiejuk J., Komentarz Świętych Ojców do Ewangelii według Św. Mateusza, Białystok 2000.

Jankowski A., Apokalipsa świętego Jana; Wstęp - przekład z oryginału - komentarz, t. XII, Poznań 1959.

Jankowski A., Dwie świątynie Ducha Świętego według listów Pawłowych, RBL1 (1988), s. $17-29$.

Jankowski A., Listy więzienne świętego Pawła. Wstęp - przekład z oryginału - komentarz, t. VIII, Poznań 1962.

Jan od Krzyża, Dzieła, Kraków 1998.

Kreft W., Kościót jako zgromadzenie liturgiczne w Liście do Hebrajczyków, RBL 4(1973)185194.

Kuckerlkorn E.A, Mateos M.D., Kraft T., Apokalipsa św. Jana, w: Międzynarodowy Komentarz do Pisma Świętego, red. W. Chrostowski, Warszawa 2000, s. 1677-1709.

Langkammer H., Nauka św. Pawła o Kościele, w: Kościół w świetle Biblii, red. J. Szlaga, Lublin 1984, s. 83-120.

Langkammer H., Ksiega Ezdrasza - Nehemiasza. Wstęp, przekład z oryginału, komentarz, eskursy, t. II, Poznań-Warszawa 1971.

Lekcjonarz mszalny, t. VI, Poznań-Warszawa 1991.

Nadolski B., Wprowadzenie do liturgii, Kraków 2004. 
Łach S., List do Hebrajczyków. Wstęp - przekład z oryginału - komentarz - eskursy, t. X, Poznań 1959.

Ozorowski E., Kościół, Wrocław 1984.

Pontyfikat Rzymski odnowiony zgodnie z postanowieniem świętego Soboru Powszechnego Watykańskiego II wydany z upoważnienia papieża Pawła VI poprawiony staraniem papieża Jana Pawła II. Obrzędy poświęcenia kościoła i ołtarza, Wydanie wzorcowe, Katowice 2001.

Sobór Watykański II, Konstytucja o liturgii świętej Sacrosanctum concilium, w: Sobór Watykański II, Konstytucje. Dekrety. Deklaracje, Poznań 2002, s. 48-78.

Pontyfikał Rzymski odnowiony zgodnie z postanowieniem świętego Soboru Powszechnego Watykańskiego II wydany z upoważnienia papieża Pawła VI poprawiony staraniem papieża Jana Pawła II. Obrzędy poświęcenia kościoła i ołtarza, Wydanie wzorcowe, Katowice 2001.

Romaniuk K., Jankowski A., Stachowiak L., Komentarz praktyczny do Nowego Testamentu, t. II, Poznań-Kraków 1999.

Słownik grecko-polski, red. Z. Abramowicz, t. II, Warszawa 1960.

Sobeczko H.J., Zgromadzeni w imię Pana, teologia znaku zgromadzenia liturgicznego, Opole 1999.

Sobeczko H.J., Zgromadzenie celebruje liturgię, w: Msza Święta - rozumieć, aby lepiej uczestniczyć. Wykład liturgii Mszy, red. J. Hadalski, Poznań 2013, s. 87-92. 